\title{
Malay Folklore "The legend of Alut Island" As a Media of Character Education Maritime Society
}

\author{
Suhardi ${ }^{1}$, Muhammad Candra ${ }^{2}$, Zaitun $^{3}$ \\ \{suhardi.tp@gmail.com¹, m.candra09@gmail.com² ${ }^{2}$ zaitun@umrah.ac.id ${ }^{3}$ \} \\ Universitas Maritim Raja Ali Haji Tanjungpinang Indonesia \\ Telp. (0771) 4500090, Fax (0771) 4500091, PO BOX 155 Tanjungpinang 29100
}

\begin{abstract}
The Maritime Society of the Riau Islands Province has various forms and varieties of folklore, for instance the Legend of the Alut Island. This legend has the value of local wisdom that is appropriate for character education media at the primary and secondary education levels. The purpose of this study is (1) to describe the educational value of Alut Island folklore characters, (2) assist teachers in providing literary teaching materials (folklore), (3) help the availability of learning materials about folklore, and to (4) introduce students about the folklore of Alut Island. This research includes qualitative research. The research method uses content analysis method. Data collection techniques using document techniques and the data analysis using structural techniques. The result of the research is that the Legend of Alut Island contains character education values, for instance religious values, hard work, and responsibility values.
\end{abstract}

Keywords: Folklore, Legend, Alut Island, Character Education

\section{Introduction}

Riau Islands province is a province that is mostly surrounded by the sea. It can be said, the area of the ocean is greater, than the land area. Therefore, the people of Riau Islands Province can be considered as Maritime Communities because the sea is an object that is used as a source of life (economic, social, political, legal, and cultural). As a source of cultural life, the sea for the people of Riau Islands Province is also a source of inspiration to generate to various forms of folklore, for instance: sagas, fairy tales, myths, legends, poetry, poetry, pantun, and so on. Various forms of folklore are now spread in several places (districts / cities).

Folklore as an asset of Malay culture certainly needs to be preserved and developed so that its existence is not extinct. In addition, so that the younger generation of Malays can know and enjoy it as an educational consumption, thus, the younger generation of Malays is expected to love it and care in preserving and expanding it. In addition, it is also expected that the younger generation can explore the richness of the values contained in it and can make it as a medium of moral education, religious, culture, and educational media (character education). Thus, the identity of the Malay that has existed so far can continue to be preserved, as the philoshopy "Takkan Melayu Hilang Di Bumi". 
Viewing the conditions that occur today, there is a concern that is felt by observers of Malay folklore, if not increased attention and action, folklore as an asset of Malay culture that has existed so far, will be lost. This loss can be caused by several things. First, the existence of native folklore figures is getting less and less in number. It is difficult today to find who is really able to master existing folklore so that it can be the source of researchers who will do existing folklore. This is much felt by the researcher when taking data into the field related to the study of folklore. Time is often wasted in vain (not in accordance with the results obtained). The researcher often find sources who only master a few existing folklore, so researcher often feel dissatisfied.

Second, the process of inheritance of folklore, from the old to the young has not worked as expected. Generally the cause comes from the side of the younger generation itself, such as: the attitude of the younger generation who consider folklore unnecessary / useless / ancient. Another attitude is not to take care, whatever, whether there is or not folklore. Both of these attitudes are certainly very detrimental to the younger generation itself. They increasingly do not know the riches and magnificience of folklore. There is a possibility, low love of young people to existing folklore because they do not know deeply in folklore. If they knew it, we would be sure their attitude would turn 180 degrees (loving folklore). It is our responsibility as researchers to provide more information to today's young people so that they love the folklore around them more.

Third, the process of transliteration of Malay literature, from oral form to writing form so far has not worked as expected. The number of Malay folklore books is still small and limited in spread. As a result, there is not much that can be known the form and diversity of Malay folklore that exists among students and folklore enthusiasts. Maybe this is also the cause, why foreign researchers have very little attention to do the study of Malay folklore that exists today. The reason is that they still have little information regarding the form and diversity of Malay folklore that exist. This is very different from what happens in the people of Java and Bali, whose people have long been accustomed to writing culture so that they have written documents that have a lot to do with their culture. Things are very different from the Malay community, which has been more accustomed to its oral culture. As a result, we are poor with written documents. We are excited, Malay figures have realized the shortcomings so far, so they began to embed a writing culture and generate to several documents related to Malay folklore.

Fourth, the existence of local content (folklore: fairy tales, legends, and myths) in the school curriculum at various levels in Riau Islands Province, has high expectation in introducing folklore early on to students so that students know, understand, and love existing folklore. However, it is unfortunate that the implementation process has many obstacles, for instance: (1) teachers who teach these subjects are not teachers who are from the background of literature faculty graduates, but teachers in other subject fields given additional assignments by the principal. The result is certainly imaginable;(2) the subjects of local content of folklore have not been supported by the availability of sufficient numbers of folklore books, which can be the reading material of students at school and at home; and (3) teachers who are given the additional task of teaching folklore subjects, often not teachers whose hobbies read folklore and the 
experience of reading folklore is still very minimal so there is not much that can be obtained by students in the classroom while the learning process takes place.

Fifth, media support (electronic and print) has been low to existing Malay folklore, such as: lifting some existing folklore into the form of film scenarios (soap operas or big screens). Even if there are already numbers that are not comparable to folklore that comes from outside. It is natural why our children today are more familiar with folklore from the outside than what is in their midst. The cause is still unknown. Is the director afraid if the film will be quiet when it is aired or indeed because the film directors do not get references about some of the best Malay folklore that already exists to be able to be lifted into a film scenario?

Sixth, throughout the observations that researchers have made so far, the results of Malay folklore studies (in the form of research) are still few in number. There are still many folklores that have not been chosen as objects of study. Both among students and lovers of Malay folklore. Some folklore that exists, there is still a lot of information on the wealth of value contained in it. Whether in the form of fairy tales, myths, or legends. Likewise in the rich form and diversity of Malay society traditions.

The purpose of this research is (1) to describe the values of character education contained in existing Malay folklore, (2) help teachers of local content subjects (folklore) at various levels of education (elementary and secondary) in the provision of teaching materials so that curriculum objectives can be achieved, (3) help students prepare learning / reading materials in local content subjects (Malay folklore), and to (4) motivate students to love existing folklore so that they have the care and responsibility to nurture and develop it going forward.

In Online KBBI (Kamus Besar Bahasa Indonesia) it is loaded that the word 'maritime' is related to something that smells of sea, sea voyage, or sea trade (https://kbbi.kemdikbud. go.id/entri/maritim). In the Alphabetical Thesaurus Indonesian [1], it is contained that the word 'maritime' is nautical, marine, maritime. Based on these two sources, the phrase "maritime community of Riau Islands Province" can be interpreted as the people of Riau Islands Province living along the coast / coast that makes the sea as a place of daily activities, people who use the sea as a source of life, or people who make the sea as inspiration to generate their creative works (such as: folklore: fairy tales, myths, and legends).

Literary works such as folklore that makes the sea as an object, can be said to be a work of Maritime Literature. Malay folklore can be said to be maritime folklore because many Malay folklore that exists uses the sea as the setting of the story, for instance: the story of the Legend of Paku Island, Tapai Island, Panglima Jangoi, Pilang Island, Senua Island, and Nasi Strait.This is as Djoko Saryono revealed in his paper on, "Seminar on Maritime Literature and Ritua; Sea: Surfing Literature, Exploring Culture" which is peddled by HISKI State University of Jakarta August 9, 2021, that Maritime Literature is a literary work that is closely related to the people of the sea / coastal / live on the beach. People who make the sea as a source of life and daily activities. Maritime literature is very interesting to study. There are 5 aspects that must receive special attention in the study of maritime literature, namely (1) how preservation steps should be done, (2) how the process of creation / generation, (3) how the study has been done so far, (5) how connoisseurs / readers so far. These five steps are also processes that must be done in the revitalization of maritime literature in the future [2]. 
According to Yock Fang (2011:1) [3], "Folk literature is literature that lives in the midst of the people. Spoken by mothers to their children while in the cradle. Likewise, the storyteller tells it to the villagers who cannot read. These folk literary forms include: stories, expressions, proverbs, songs, dances, traditional customs, laws, puzzles, folk games, beliefs, and celebration." So, it can be concluded that folklore is part of literature or folk literature.

The study of folklore certainly has many benefits. First, it provides information about the way of thinking of a particular group of people. Second, providing information about people's lifestyles. Third, providing information about problems that have occurred in community groups [4]. As for the form of folklore there are 3 groups, namely: myths, legends, and fairy tales [5]. Folklore as a product of oral literature remains an interesting study to this day. According to Ong [6] oral literature has always existed in human life as a basic authorship or reflection of native human culture, and cannot be underestimated.

The Research and Development Agency for the Curriculum and Books Center of the Ministry of Education and Culture in 2011 has compiled a book related to character education. The book contains 18 types of character education, such as: (1) religious, (2) honest, (3) tolerance, (4) discipline, (5) hard work, (6) creative, (7) independent, (8) democratic, (9) curiosity, (10) spirit of nationality, (11) love of the homeland, (12) appreciate achievement, (13) friendly / communicative, (14) peace love, (15) love to read, (16) care about the environment, (17) social care, and (18) Responsibility. This Eighteen values of local wisdom used as a basis for folklore analysis that is used as a sample.

Based on the results of the researcher's monitoring, there are several folklore studies that have been done by previous researchers. Novi Anugrajekti (2021) [7] with the title, "Ritual Laut Muncar dalam perspektif Ekowisata." The results of the research obtained are sea rituals that are always commemorated by the Muncar community has become ecotourism so that it makes a positive contribution to the progress of the world of tourism. Muncar sea ritual is not only an element of community entertainment but also as a tourist event.

Junaini, Agustina, and Canrhas. In 2017 [8] through the title of her research "Analysis of the Value of Character Education in Seluma Folklore" obtained the results of her research that Seluma folklore contains the value of character education courage, mutual attitude, discipline, self-respect, fairness, caring, mutual protection, respect for others, deliberation, and the value of gotong royong. Furthermore, Merdiyatna in 2019 [9] raised the title "Cultural Values in Panjalu Folklore". The results of the research obtained are Panjalu folklore contains noble cultural values, local wisdom, and wisdom. Suhardi and Riau Wati in 2017 [10] raised the research title "Analysis of Cultural Values (Malay) in Oral Literature of Tanjungpinang City Community." The results of the research obtained are oral literature of the people of Tanjungpinang city contains cultural values (Malay), such as the value of responsibility to yourself, society and the environment.

Another researcher, who also conducted research related to folklore is Arief Setyawan in 2017 [11]. The title of his research is "Content of Character Education in Folklore in Pacitan." The results of the research obtained are Folklore from Pacitan as a literary work containing the educational value of characters that include: (1) religious; (2) Honest; (3) hard work; (4) 
creative; (5) curiosity; (6) the spirit of pride; (7) appreciate performance; (8) peace love; (9) care about the environment; (10) social care; and (11) answer. These values become the basis that folklore in addition to being used as a medium to introduce stories that are believed by ancestors to their descendants, can also be a means of educating characters in themselves.

\section{Method}

This research uses a method of content analysis, namely the content of a communication, especially verbal communication in the form of language [11]. Furthermore, the data was collected using document techniques (Malay folklore), namely the Legend of Alut Island. While data analysis uses structural analysis techniques, namely describing existing story units (plots). Furthermore, explain (interpret) according to relevant theories to find the values of character education in the story [9].

\section{Results and Discussions}

\subsection{Results}

Malay folklore that until now is still preserved and developed by the maritime community of Riau Islands Province is the "Legend of Alut Island". Alut Island is one of the islands located in Lingga Regency, precisely in North Lingga subdistrict. The word "alut" means ship. Alut Island is a ship-shaped island. This island has a story. It is said that there used to be a child who disobeyed his mother. The boy's name was Alut. Alut and his mother lived in an old hut, not far from the harbor where the large ships were leaning.

Alut after adulthood migrated and left his mother alone in the village. Having always worked hard in the region, Alut eventually became a successful young man. He was appointed captain of a large ship. Day by day Alut's life is getting better. Once the ship that Alut was riding stopped on an island. The island is none other than his own homeland and the place of his mother who has always longed for his arrival.

One morning, Alut's mother got word that her son's ship named Alut docked at the port to fill the water and food supplies to sail. His mother was also informed that his son had now become a successful man, a captain of a large ship, and was wealthy. That same day the mother came to the port where her son's boat was leaning. He brought some of her son's favorite food. In the heart of Alut's mother has been imagined, surely her son is now an adult. He has become a brave man. Her life will soon be good because her son has succeeded.

What Alut's mother imagined turned out to be very different. Alut did not like to come to his mother who looked already hunched, shabby and poor. Alut didn't admit that it was his mother. Even Alut rudely drove his mother to leave his ship. It was heartbroken for his mother at the time. She could only cry out of her son's boat. Now Alut's mother was furious. Alut's mother prayed to God that her son's ship would be sunk in the middle of the sea as a lesson because it had done badly to her own mother. Shortly after the ship left the ship, it was buffeted by strong winds and sank. Then came an island. The local people call it Alut Island.

\subsection{Discussions}


Based on the storyline and the content of the story contained in the legend of Alut Island, a content analysis can be carried out, in the form of the values contained in it.

\section{1) Religious Values}

The legend of Alut Island contains religious values, namely an unrequited child, a child who disobeys his own mother, and a child who does not follow the teachings of Islam. A child can ideally give affection to his mother or both parents as they have done, having raised him into adulthood. Even the mother had been pregnant for 9 months in difficult circumstances and the struggle between life and death during her birth. It is a great sin when a child is rude to his parents. In Islamic teachings it is said that if a child wants to taste the pleasures of the surge in the hereafter then happy both parents (fathers). The word of Allah in Al-Quran states:

$$
\text { “...do good to both your parents” (An-Nisa':36). }
$$

The 36th verse of Surat An-Nisa clearly warns us as children to always do good to our parents. Al-Quran in the next verse also states:

$$
\begin{aligned}
& \text { "...Do the best you can to your parents. If both are old and in your } \\
& \text { care, then do not say to them the words "ah", do not snap at them, } \\
& \text { and speak glorious words to them.." (QS: Al-Isra ayat 23-24). }
\end{aligned}
$$

The meaning of the verse is that we as children are obliged to do good with our mother and father. Especially when they are old, it is our duty as children to love and love them. As children, we are forbidden to speak words that can hurt our hearts or feelings. Use words that show them words.

Another verse relating to the obligation to do good to a child to both parents is also found in Al-Quran, namely:

\section{“...Do good to your parents! Give thanks to Me and to your parents, only to Me will you return.” (QS Luqman: 14).}

From some verses in the Qur'an it is clear that we as children must do good to both parents (father and mother). Don't be rude to both. Say kind words to them (your mothers)!

Alut's character could drive his mother away, when his mother missed him terribly. His mother was very proud to see that her son had succeeded. But what Alut's mother got was the rudeness of speech spoken by the child who had been very dreamed of taking refuge in his old age. Alut has the heart to make his mother sad crying sobbing. Alut could be rude to his own biological mother to the point of dragging her outside the ship. It was outrageous to Alut's actions to his mother. Alut deserves a great punishment from God. This is as happened in the story, Alut's ship was sunk by God through a large wave that came crashing his ship until it sank and made the island with his ship.

\section{2) The Value of Hard Work}

The change of Alut's character from an ordinary person, as a large crew member until he was successfully appointed as the captain of a large ship is clearly a result of hard work done by Alut figures. Hard work until he was successfully appointed captain of the great ship also by the intervention of God. The success achieved by Alut figures should be more grateful to God. 
Did Not God say clearly that if his people were grateful for the blessings and gifts He gave, God would have added them from unexpected doors? On the contrary, Allah also warns that whoever is not grateful for the blessings that have been given, Allah will bring down His cruel punishment.

Alut included a figure who was ungrateful to God for the abundance of sustenance he received. He became arrogant and forgotten himself. God warns in the Qur'an against proud people:

\begin{abstract}
"Worship God, and do not associate him with anything. And do good to your parents, relatives, orphans, the poor, close neighbors and distant neighbors, and your colleagues, ibn sabil and servants. God does not like those who are proud and proud of themselves." (An-Nisa:36)
\end{abstract}

He was embarrassed to see his mother who was already bad, hunched, and weak until he could be rude to his own biological mother. God certainly doesn't like this. God sent down his punishment to the Alut. All his possessions, including his own, were sunk by God into the sea. This can really be a lesson for those of us who see and read this story, to always give thanks to God and ask that the sustenance we get is always blessed by God. It's a lesson to always respect and love our parents. The blessings of life will come if we always love our parents and always give blessings to God.

\title{
3) Value of Responsibility
}

The legend of "Alut Island" also contains the value of responsibility in it. Alut is a character who does not have a sense of responsibility to his own mother. Supposedly, after he was successful and successful in working, in addition to being responsible to his wife and children, Alut also had a responsibility to make his mother happy. Did not the figure of Alut when asking permission to leave the house promised if he was successful in the region, he would return to the village to make his mother himself happy. However, what happened? Alut did not keep his promise. He ran away 100 percent of his promise. Never mind sending his mother money for daily shopping, just going to his mother he does not want to.

Alut's character is even ashamed to have a poor and shabby mother. Alut does not realize that he comes from his poor and shabby mother. If the character Alut has a sense of responsibility, Alut's character should give a lot of money or property to his birth mother so that his mother becomes a rich man. Likewise, if the character of Alu sees his mother who is shabby and ugly, the character should buy good clothes for his mother, buy gold in the form of rings, necklaces, bracelets, and so on so that his mother looks luxurious. However, none of this was done by Alut. Alut was just hateful, ashamed, and didn't want to do much for his own mother. This attitude is clearly the attitude of a child who is not grateful to both parents.

Based on the contents of this Alut Island legend and the values of character education contained in it, the Legend of Alut Island can be used as a medium of character education, especially for students in elementary and secondary education levels. Through this Legend of Alut Island, students can be invited by their teachers to think and behave right through Alut figures, such as: how to respect and love both parents (father and mother). In other words, the material of the Legend of Alut Island can be used as teacher teaching material in the classroom in order to foster good student character.

Stories similar to the legend of Alut Island actually still exist, such as: Legend of Tapai Island, and Legend of Pilang Island. The folklore is also themed children who are not grateful 
to their parents. The Bachelor figure in the Legend of Tapai Island also ended tragically, drowning with his ship in the ocean. Pilang figures in the legend of Pilang Island are also the same, namely drowning with his ship in the ocean and becoming an island.

\section{Conclusions and Suggestions}

Based on the results of the analysis that has been done it can be concluded that the Legend of Alut Island contains the value of character education, such as: religious values, hard work, and the value of responsibility. Judging from the aspect of religious values (teachings of Islam), Alut figures are figures who have attitudes contrary to the teachings of Islam, namely children who must be polite, loving, and loving both parents. From the aspect of hard work, Pilang figures are hard workers to successfully become a respected person. However, his success made him arrogant and strayed into the path of not true. From the aspect of responsibility, Alut is an irresponsible figure, especially to his own mother. Alut Island folklore is very suitable to be chosen as teaching material and studying in the classroom. Through this folklore, students have indirectly instilled an attitude of respect for both parents at home.

\section{References}

[1] Anugrajekti, N. (2021). Ritual Laut Muncar dalam Perspektif Ekowisata. Seminar Sastra Maritime Dan Ritual Laut: Melayari Sastra, Menelisik Kebudayaan.

[2] Badan Penelitian dan Pengembangan Pusat Kurikulum dan Perbukuan. (2011). Buku Pedoman Pendidikan Karakter. Kemendikbud.

[3] Dananjaya, J. (1991). Folklor Indonesia: Ilmu Gosip, Dongeng, dan lain-lain (3rd ed.). PustakaUtama Grafiti.

[4] Endraswara, S. (2018). . Antropologi Sastra Lisan: Perspektif, Teori, \& Praktik Pengkajian. Yayasan Obor Indonesia.

[5] Fang, L. Y. (2011). Sejarah Kesusastraan Melayu Klasik. Yayasan Pustaka Obor Indonesia.

[6] Junaini, E. dk. (2018). Nilai Pendidikan Karakter Cerita Rakyat Seluma. https://ejournal.unib.ac.id/index.php/korpus/article/view/3202

[7] Merdiyatna, Y. Y. (2019). Nilai-Nilai Budaya dalam Cerita Rakyat Panjalu. https://jurnal.uisu.ac.id/index.php/Bahastra/article/view/1715

[8] Sudikan, S. Y. (2015). Metode Penelitian Sastra Lisan. Pustaka Ilalang Group.

[9] Sugono, D. (2009). Tesaurus Alfabetis Bahasa Indonesia. Balai Pustaka.

[10] Suhardi. (2021). Foklore Melayu: dalam Bentuk dan Keragamannya. Deepublish.

[11] Suhardi, S., \& Riauwati. (2017). Analisis Nilai-Nilai Budaya (Melayu) dalam Sastra Lisan Masyarakat Kota Tanjungpinang. Lingua Jurnal Bahasa Dan Sastra, 13(1), 2533. https://journal.unnes.ac.id/nju/index.php/lingua/article/view/8755/5736 